\title{
Implementation of Environmental Health Management to Achieve Open Defecation Free in Tamansari Village in Bandung
}

\author{
Raden Ganang Ibnusantosa, Susan Fitriyana, Nurul Romadhona, Titik Respati \\ Department of Public Health, Faculty of Medicine, Universitas Islam Bandung, Bandung, Indonesia
}

\begin{abstract}
Proper sanitation will ensure the community is healthy and reduce most infectious diseases' transmission, especially water-borne diseases. Open defecation has a significant effect on public health. Sanitation coverage data from the Ministry of Health Republic of Indonesia in 2018 shows that open defecation is still high, including in Bandung city. This study aims to analyze the implementation of environmental health management programs that have been implemented in Tamansari village in Bandung city. This research is a qualitative research conducted in Tamansari village in Bandung city. The data were collected from May to August 2021 through Focus Group Discussion with cadres and in-depth interviews with informants from the village head, a representative from a non-governmental group, and cadres. The results of this study indicate that the process of planning, organizing, mobilizing, and controlling has been running according to the theory. Obstacles faced by the village in achieving open defecation free include funds, land, community understanding, and sub-optimal supervision.
\end{abstract}

Keywords: Environmental health, management, open defecation

\section{Penerapan Manajemen Kesehatan Lingkungan untuk Mencapai Bebas Buang Air Besar Sembarangan di Kelurahan Tamansari Bandung}

\begin{abstract}
Abstrak
Sanitasi yang layak akan memastikan masyarakat berada dalam lingkungan yang sehat dan mengurangi sebagian besar penularan penyakit infeksi terutama penyakit yang ditularkan melalui air. Buang air besar (BAB) sembarangan memiliki efek yang sangat besar bagi kesehatan masyarakat. Data cakupan sanitasi dari Kementerian Kesehatan Republik Indonesia tahun 2018 menunjukkan bahwa perilaku BAB sembarangan masih tinggi termasuk di Kota Bandung. Penelitian ini bertujuan menganalisis penerapan program manajemen kesehatan lingkungan yang telah dilaksanakan di Kelurahan Tamansari Kota Bandung. Penelitian ini merupakan penelitian kualitatif yang dilakukan di Kelurahan Tamansari Kota Bandung. Pengambilan data dilakukan pada bulan Mei hingga Agustus 2021 melalui Focus Group Discussion dengan kader dan wawancara mendalam dengan lurah, perwakilan kelompok swadaya masyarakat, dan kader. Hasil penelitian ini menunjukkan bahwa proses perencanaan, pengorganisasian, penggerakan, dan pengawasan sudah berjalan sesuai dengan teori. Kendala yang dihadapi oleh kelurahan dalam mencapai bebas BAB sembarangan antara lain dana, lahan, pemahaman masyarakat, dan pengawasan yang belum optimal.
\end{abstract}

Kata kunci: BAB sembarangan, kesehatan lingkungan, manajemen

Received: 10 June 2021; 24 December 2021; Accepted: 30 December 2021; Published: 31 December 2021

Correspondence: Raden Ganang Ibnusantosa, dr., MMRS. Department of Public Health, Faculty of Medicine, Universitas Islam Bandung. Jln. Tamansari No. 22, Bandung 40116, West Java, Indonesia. E-mail: ganangibnusantosa@gmail.com 


\section{Introduction}

Open defecation refers to the practice of defecating in fields, forests, bushes, open water, beaches, or other open places. ${ }^{1-3}$ Open defecation has a significant effect on public health. Human waste contamination and poor hygiene behavior are still the highest causes of death in children, lack of nutrition, and stunting. ${ }^{2,3}$

Through Health Law Number 36 of 2009, the government of the Republic of Indonesia states that environmental health is held to realize a healthy environmental quality. ${ }^{4}$ A healthy environment includes sanitation facilities and drinking water facilities that meet the requirements in settlements and public places. ${ }^{5}$

Health Law Number 36 of 2009 is in line with Blum's theory which states that environmental factors and behavioral factors are the most critical determinants of human health. Proper sanitation will ensure the community is in a healthy environment and reduce most of the transmission of infectious diseases. ${ }^{6}$

Based on data on sanitation coverage from the Ministry of Health in 2018, only 28 cities and one province managed to get the stop open defecation status in Indonesia. It shows that the behavior of open defecation is still high, including in Bandung city. ${ }^{7}$

Good environmental health management is needed to get the status of open defecation free. Therefore, this study aims to analyze the implementation of environmental health management programs implemented in a Tamansari village in Bandung city.

\section{Methods}

This research is a qualitative research conducted in Tamansari village in Bandung city. Data were collected through Focus Group Discussion with cadres and in-depth interviews with six people (the village head, representatives of nongovernmental organizations, and cadres).

The results of the Focus Group Discussion and in-depth interviews were recorded, then the recordings were made into a transcript. The transcripts were then processed by grouping the statements based on the emerging themes. The existing themes are coded to facilitate data processing using Microsoft Word 2019. The data was taken from May to August 2021. The data taken included the management process and the obstacles in the village in achieving the open defecation free status. This study was approved by the Universitas Islam Bandung Health Research Ethics Committee.

\section{Results}

Researchers conducted in-depth discussions regarding the management process implemented to achieve the open defecation free predicate during in-depth interviews.

We should follow the planning, organizing, actuating, and controlling (POAC) theory in carrying out environmental health management. Planning includes determining organizational goals, establishing strategies to achieve these goals, and developing plans to integrate and coordinate administrative work. After that, the organizing step is carried out: dividing work among group members and making provisions in the necessary relationships. After organizing, the actuating step is carried out, aiming to make all group members work together to achieve the goal. And lastly, controlling is an activity that ensures that the work goes well by monitoring performance and taking necessary corrective actions. $^{8-11}$

Respondents answered about the planning process, the organizing process, the implementation process, and the method of controlling the installation of communal bio tanks to achieve the open defecation free predicate.

In the planning stage, these results were explored:

"We do various breakthroughs, however important communal things can be built. We do not rely on the Bandung city government budget. However, we also apply for assistance to the central government through the Ministry of Public Works and Housing, and we also coordinate with the Citarum Harum Task Force...." (LRH.P1.1)

The village has invited various parties to assist in constructing a communal septic tank. The planning for installing this communal septic tank has several obstacles, including lack of funds, narrow land, and community rejection due to poor public understanding of the function of communal septic tanks.

"....we have coordinated with the Department of 
Housing, Settlements, Land, and Landscaping Office in charge of this open defecation free program, a survey has been carried out together with Citarum Harum Task Force, and the Healthy Bandung Forum will be assisted with the piping process. Regional drinking water companies will also assist the drainage of this communal septic tank...." (LRH.O1.1)

Village has appointed parties invited to cooperate. The maintenance of the communal septic tank is handed over to the neighborhood units (rukun tetangga, RT) and community units (rukun warga, RW) without special management, as stated by the non-governmental group representative:

"....later, it will be handed over to the local RT and $R W$ as beneficiaries, of course also with some things that were discussed first in the care and responsibility of the community and its management...." (KSM.01.1)

The $100 \%$ open defecation free status can be achieved by installing communal septic tanks and installing wastewater treatment plants (instalasi pengolahan limbah, IPAL) and independent septic tanks. However, installing a IPAL requires more funds and land. In contrast, installing a separate septic tank depends on land ownership and funds owned by residents. Therefore, the installation of bio tanks is still needed in this village area.

The beneficiary area of this communal bio tank must be higher than the installed communal bio tank. Therefore, communal bio tanks are stored underground so that they are lower than the toilets of the beneficiary residents. However, this village is a densely populated area on the banks of the river. Therefore, the installation of communal bio tanks by planting cannot be done because it will require more funds and energy to dismantle people's houses. Thus, the toilets of the beneficiary residents are higher than the communal bio tank. Therefore, the installed communal bio tank is placed on the river's banks that flows in the village.

The installation of communal bio tanks on the river banks also faces obstacles. The two bio tanks measuring five cubic meters cannot be brought to the riverbanks through residential areas because the public roads are insufficient. Therefore, the bio tanks are brought to the installation site through the river.

As previously stated, this village is densely populated with a narrow land area. Therefore, the area management must carry out a strategy to install bio tanks. The strategy that has been carried out is to install communal bio tanks beyond the capacity specified by the factory, as stated by the non-governmental organizations representative:

"....with the proper capacity, the regulation is for 80 people at most, but for what we install now, it is up to 120 people...." (KSM.A1.1)

When installing the communal bio tank, the toilet drains connected to the bio tank drains feces and drains bathwater and dishwashing water containing soap. The soap carried into the bio tank will affect the decomposing bacteria in the bio tank. To overcome the problem of excess capacity and water lines that are mixed with soap, non-governmental organizations overcomes it by increasing the frequency of providing decomposing bacteria and chlorine, as stated:

"....to get around that, we give the bacteria and chlorine more often, from once every six months to once a month, so that the bacteria are better able to break down the dirt whose water has been mixed with bath soap or dishwashing soap...." (KSM.A1.3)

\section{Discussion}

Robbins and Coulter ${ }^{8}$ stated that planning activities involve determining organizational goals, establishing strategies to achieve these goals, and developing plans to integrate and coordinate organizational work. The planning step includes formulating what must be done and how.

In planning the construction of a communal septic tank, the local village head prioritizes constructing a communal septic tank in the riverbank area. This priority follows the results of Paladiang et al.'s $\mathrm{s}^{12}$ research, which states that there is a significant relationship between open defecation behavior and the distance of the house being close to the river.

The village is planning steps encountered several obstacles, including limited funds, narrow land, and inadequate public understanding of communal septic tanks. 
This village's ownership of funds is an obstacle in achieving the open defecation free predicate. It follows the research results by Rathomi and Nurhayati, ${ }^{13}$ which states that the cost factor is the main obstacle in having healthy latrines and the cause of open defecation practices. To overcome this, the local village head tries to find opportunities to cooperate with both the central government and seek CSR.

In addition to funding problems, the next problem faced in installing communal septic tanks in this village is limited land. It is also following Sugiharto and Nurhayati's ${ }^{14}$ research which states that limited land is one of the obstacles in reducing open defecation behavior.

The obstacle in implementing the planning is the community's refusal due to a lack of public understanding about the function of the communal septic tank. It is in line with Rathomi and Nurhayati's ${ }^{13}$ research, which concluded that people who are well informed with a positive attitude are more likely not to practice open defecation.

Robbins and Judge ${ }^{15}$ state that organizing determines what tasks are to be done, who is to do them, how the tasks are to be grouped, who reports to whom, and where decisions are to be made.

In dealing with open defecation and communal bio tanks, the local village head has collaborated with related parties from the central government, regional drinking water companies, community organizations, and residents. In maintaining the communal bio tank that has been installed, nongovernmental organizations will be formed, which will be handed over directly to the local RT and RW management. It is following the organizing process, according to a previous study. Thus, there are no significant obstacles when carrying out the organization in building a communal bio tank..$^{10}$

A previous study expressed that actuating makes all group members want to work together and work sincerely and willingly to achieve goals following planning and organizing efforts. ${ }^{10}$

In their research, Nandita et al. ${ }^{16}$ stated that the program implementation process was one of the factors that influenced the open defecation free program. Therefore, problems in actuating this program need special attention to achieve open defecation free status.

The implementation of the communal bio tank development is going well. All technical problems encountered in the field can be adequately discussed with all work equipment. In addition, residents involved in constructing communal bio tanks are given education and examples of bio tanks built to understand the functions and benefits of installing bio tanks to increase motivation at work.

The obstacles faced during the communal bio tank development implementation are technical constraints predicted from the planning process. The narrow land constraint can be overcome by building communal bio tanks on the riverbanks. Obstacles in mobilizing the bio tank because its size is not enough to enter the residents' housing can also be overcome by bringing the bio tank through the river.

Controlling is an activity that ensures that the work goes well by monitoring performance and taking necessary corrective actions. ${ }^{11}$

Non-governmental organizations carry out the controlling process of installing bio tanks and pipelines. In contrast, administrators from RT and RW carried out the controlling process for maintaining the installed bio tanks.

The obstacle faced in controlling is a monitoring process that has not been optimal in one of the installed bio tanks. It resulted in residents' latrines connecting to the bio tank to re-flow their waste into the river. Residents who were previously accustomed to defecating in the toilet returned to practicing open defecation. This finding follows the research results by Yulyani et al., ${ }^{17}$ which stated that the ownership of healthy latrines influences open defecation behavior in urban areas.

\section{Conclusions}

This study shows that the implementation of environmental health management to achieve open defecation free in Tamansari village has been running according to POAC theory. There are no new findings obtained from this study. Most of the obstacles are in the planning process, where funds, limited land, and people lack understanding about communal septic tanks. However, constraints in the planning process were successfully overcome with cooperation, modification of the installation of communal bio tanks, and education to the public. The next obstacle is in the controlling process, where there are incidents of communal bio tanks being damaged due to inadequate supervision. It has 
been evaluated and corrected by appointing the management formed from the RT and RW, who are the beneficiaries of the communal bio tank.

\section{Conflict of Interest}

The authors declare no conflict of interest.

\section{Acknowledgment}

We would like to thank all students who participated in this study.

\section{References}

1. Patunru AA. Access to safe drinking water and sanitation in Indonesia. APPS. 2015;2(2):234-44.

2. United Nations Children's Fund. Water and sanitation [Internet]. New York: United Nations Children's Fund; 2021 July [cited 2022 January 21]. Available from: https:// data.unicef.org/topic/water-and-sanitation/ sanitation.

3. United Nations Children's Fund. UNICEF's game plan to end open defecation [Internet]. New York: United Nations Children's Fund; 2018 April [cited 2021 August 6]. Available from: https://www.unicef.org/ media/91316/file/Game-plan-to-end-opendefecation-2018.pdf.

4. Undang-Undang Republik Indonesia Nomor 36 Tahun 2009 tentang Kesehatan.

5. Kementerian Kesehatan Republik Indonesia. Laporan kinerja kegiatan kesehatan lingkungan tahun 2019 [Internet]. Jakarta: Kementerian Kesehatan; 2020 March 9 [cited 2021 August 7]. Available from: http://kesling.kesmas.kemkes.go.id/ new/kemenkes/fasyenkesdashboard/ artikeldetail/detail/59.

6. Sulistiarini, Hargono R. Hubungan perilaku hidup sehat dengan status kesehatan pada masyarakat Kelurahan Ujung. J Promkes.
2018;6(1):12-22.

7. Kementerian Kesehatan Republik Indonesia. Data, temuan, dan rekomendasi STMB [Internet]. Jakarta: Kementerian Kesehatan Republik Indonesia; 2018 November 16 [cited 2021 August 9]. Available from: http://stbm. kemkes.go.id/review_stbm/findings.html.

8. Robbins SP, Coulter M. Management. Global edition. $14^{\text {th }}$ Edition. London: Pearson; 2018.

9. Arifin S, Rahman F, Wulandari A, Anhar VY. Buku ajar dasar-dasar manajemen kesehatan. Banjarmasin: Pustaka Banua; 2016.

10. Badrudin. Dasar-dasar manajemen. Bandung: Alfabeta; 2015.

11. Schermerhorn JR Jr, Osborn RN, Hunt JG, Uhl-Bien M. Organizational behaviour. $12^{\text {th }}$ Edition. New Jersey: Wiley; 2011.

12. Paladiang R, Haryanto J, Has EMM. Determinan perilaku buang air besar sembarangan (BABS) di Desa Kiritana Kecamatan Kambera. Indones J Commun Health Nurs. 2020;5(1):33-40.

13. Rathomi HS, Nurhayati E. Hambatan dalam mewujudkan open defecation free. JIKS. 2019;1(1):68-73.

14. Sugiharto M, Nurhayati. Upaya pemerintah daerah untuk meningkatkan cakupan desa ODF (open defecation free) di Kabupaten Muaro Jambi, Sumedang, dan Lombok Barat. Bul Penelit Sist Kesehat. 2019;22(1):62-71.

15. Robbins SP, Judge TA. Organizational behaviour. Global edition. $17^{\text {th }}$ Edition. London: Pearson; 2016.

16. Nandita A, Respati T, Arief F. Faktor-faktor yang memengaruhi pilar stop buang air besar sembarangan pada program sanitasi total berbasis masyarakat di Puskesmas Cikalong Kabupaten Tasikmalaya. JIKS. 2020;2(1):314.

17. Yulyani V, Febriani CA, Shaharuddin MS, Hermawan D. Patterns and determinants of open defecation among urban people. Kesmas. 2021;16(1):45-50. 